This document was prepared in conjunction with work accomplished under Contract No. DE-AC09-96SR18500 with the U. S. Department of Energy.

\title{
DISCLAIMER
}

This report was prepared as an account of work sponsored by an agency of the United States Government. Neither the United States Government nor any agency thereof, nor any of their employees, makes any warranty, express or implied, or assumes any legal liability or responsibility for the accuracy, completeness, or usefulness of any information, apparatus, product or process disclosed, or represents that its use would not infringe privately owned rights. Reference herein to any specific commercial product, process or service by trade name, trademark, manufacturer, or otherwise does not necessarily constitute or imply its endorsement, recommendation, or favoring by the United States Government or any agency thereof. The views and opinions of authors expressed herein do not necessarily state or reflect those of the United States Government or any agency thereof.

This report has been reproduced directly from the best available copy.

Available for sale to the public, in paper, from: U.S. Department of Commerce, National Technical Information Service, 5285 Port Royal Road, Springfield, VA 22161, phone: (800) 553-6847, fax: (703) 605-6900

email: orders@ntis.fedworld.gov

online ordering: http://www.ntis.gov/help/index.asp

Available electronically at http://www.osti.gov/bridge

Available for a processing fee to U.S. Department of Energy and its contractors, in paper, from: U.S. Department of Energy, Office of Scientific and Technical Information, P.O. Box 62, Oak Ridge, TN 37831-0062,

phone: (865)576-8401,

fax: (865)576-5728

email: $\underline{\text { reports@ adonis.osti.gov }}$ 


\section{Loading Capacities for Uranium, Plutonium and Neptunium in High Caustic Nuclear Waste Storage Tanks Containing Selected Sorbents.}

\section{Authors:}

\section{Lawrence N. Oji}

Savannah River National Laboratory

Building 773-43A

Aiken, SC 29808

Lawrence N. Oji (BS, Mathematics, Trinity International University, Deerfield ILL, 1980; Ph.D. Physical chemistry, The University of Arkansas, Fayetteville, 1986), is a Principal Research Scientist at the Savannah River National Laboratory (SRNL). He has more than 10 years of industrial research experience in ion-exchange characterization and application, chemistry of High-Level Waste and stabilization of radioactive waste. Current research interests include chemistry of cesium, tritium, actinide and mercury "getters" and chemistry of aluminosilicates in nuclear waste processing.

\section{Mary E. Stalling}

Savannah River National Laboratory

Building 773-43A

Aiken, SC 29808

Mary E. Stalling (BS, Chemistry, Paine College, 1999) is a Senior Scientist at the Savannah River National Laboratory (SRNL) with more than 4 years of experience in the characterization and chemistry of high-level nuclear waste. Current research interests include chemistry of tetraphenylborate associated with high-level nuclear waste, and nuclear waste characterization.

\section{David T. Hobbs}

Savannah River National Laboratory

Building 773-43A

Aiken, SC 29808

David T. Hobbs (BS, Chemistry, University of North Carolina at Chapel Hill, 1974; Ph.D, Inorganic chemistry, Vanderbilt University, 1979) is an Advisory Senior Scientist at the Savannah River National Laboratory (SRNL) with more than 20 years of experience in the characterization and chemistry of high-level nuclear waste. Current research interests include a better understanding of actinide and inorganic chemistry associated with high-level nuclear waste, development of improved pretreatment processes, and insitu characterization techniques.

Total number of pages: 26

Total number of Figures: 10

Total number of Tables: 3 
WSRC-MS-2004-00822

\section{ABSTRACT}

In this study the loading capacities of selected actinides onto some of the most common sorbent materials which are present in caustic nuclear waste storage tanks have been determined. Some of these transition metal oxides and activated carbons easily absorb or precipitate plutonium, neptunium and even uranium, which if care is not taken may lead to unwanted accumulation of some of these fissile materials in nuclear waste tanks during waste processing.

Based on a caustic synthetic salt solution simulant bearing plutonium, uranium and neptunium and "real" nuclear waste supernate solution, the loading capacities of these actinides onto iron oxide (hematite), activated carbon and anhydrous sodium phosphate have been determined. The loading capacities for plutonium onto granular activated carbon and iron oxide (hematite) in a caustic synthetic salt solution were, respectively, $3.40 .22 \pm$ and $5.5 \pm 0.38 \mu \mathrm{g}$ per gram of sorbent. The loading capacity for plutonium onto a typical nuclear waste storage tank sludge solids was $2.01 \mu \mathrm{g}$ per gram of sludge solids.

The loading capacities for neptunium onto granular activated carbon and iron oxide (hematite) in a caustic synthetic salt solution were, respectively, $7.9 \pm 0.52$ and $>10$ $\mu \mathrm{g}$ per gram of sorbent. The loading capacity for neptunium onto a typical nuclear waste storage tank sludge solids was $4.48 \mu \mathrm{g}$ per gram of sludge solids. A typical nuclear waste storage tank solid material did not show any significant affinity for uranium. Sodium phosphate showed significant affinity for both neptunium and uranium, with loading capacities of 6.8 and $184.6 \pm 18.5 \mu \mathrm{g}$ per gram of sorbent, respectively. 
WSRC-MS-2004-00822

\section{INTRODUCTION}

Millions of gallons of high-level radioactive and caustic chemical liquid and sludge wastes are currently stored in various U.S. Department of Energy (DOE) sites such as the Savannah River and Hanford sites. These radioactive wastes are stored underground in several million-gallon holding tanks. The nuclear wastes were accumulated over several years of processing for uranium enrichment and the extraction for trace quantities of plutonium. The nuclear wastes were derived from a myriad of complex process technologies that used many chemicals (nitric acid, sodium hydroxide, bismuth phosphate, tributylphosphate methyl isobutyl ketone dibutyl butyl phosphate and a batch of other chemical, solvents, oils, mercury). Most of these chemicals used in the extraction process along with stray radionuclides are now stored in these huge waste tanks at these sites awaiting treatment and eventual stabilization of the contents. The contents of these huge tanks are not only environmental nightmares but have also become security problems in these days of terrorist threats.

These storage tanks do not only contain a simple phase of liquids but also contain solids and sludge materials which have been identified to include activated carbons, aluminosilcates, transition metal oxides, organic and inorganic resin moieties and phosphates and, of course, organic compound with various chelating characteristics.

Current DOE cleanup efforts aimed at decontaminating and stabilizing the relatively dilute nuclear tank wastes and their contents involves the concentration of the liquid fraction (supernate) of the waste to minimize space required for storing more waste and the transfer of the concentrate to other tanks for storage. Of concerns to people charged with processing these nuclear waste is the fact that the exact properties of the solid components of these tanks are not well known, especially when it comes to the 
WSRC-MS-2004-00822

ability of some of these materials to absorb or precipitate and accumulate fissionable radionucles like uranium and plutonium from the supernate to the bottom of the tanks. If the processing of these large volumes of nuclear waste with traces of fissionable materials in the supernate phases leads to unguarded concentration of radionulcides this could lead to criticality problems in the processing of the concentrates.

With the potential for the accumulation of fissile material due to precipitation or absorption by sorbents in the tank waste in mind, this investigation was designed to determine the loading capacities of common supernate actinides (plutonium, neptunium and uranium) onto the most common sorbents, activated carbon, hematite and sodium phosphate found in some nuclear waste storage tanks.

Activated carbon, iron oxides and sodium phosphate are three of the many materials which have been identified as components of some nuclear waste storage facilities at the Savannah River Site (SRS) ${ }^{1,2}$. Activated carbons, it is known, may have been introduced into some of the nuclear waste tanks at SRS as a result of back flushing activities at the Effluent Treatment Facility (ETF) carbon beds. In this process, the carbon fines end up as evaporator bottoms which are eventually transferred into some of the tanks. Iron, on the other hand, exists in various oxidation forms, mostly in the $\mathrm{Fe}^{3+}$ and $\mathrm{Fe}^{2+}$ oxidation states.

Loading tests to determine the worst case scenario loading capacities for plutonium, neptunium and uranium onto "neat" commercial materials, which are identified components of nuclear waste storage tanks sludge bottoms, were performed. Absorption and loading tests were also performed with "real" nuclear waste sludge to verify the ability of solid sludge fractions of the tank wastes to pull radionuclides out of 
WSRC-MS-2004-00822

synthetic salt solutions (spiked with plutonium, neptunium and uranium) and real nuclear waste supernate.

\section{EXPERIMENTAL}

To verify that tank sludge bottoms or their components are capable of precipitating or pulling out of solution and concentrating actinides from tank supernates, absorption and loading tests were performed with air-dried tank sludge bottom solids and identified commercial "neat" sludge components. The word "neat" as used here refers to the fact that the absorbing materials which are some of the components of nuclear waste storage tanks, for example granular activated carbon (GAC) and hematite (iron oxide) were used as-received from various commercial sources. These two classes of solids (airdried nuclear waste tank storage sludge bottom solids and identified sludge bottom components) were contacted with "real waste" (radioactive supernate solution) and synthetic salt solution or supernate simulant bearing plutonium, neptunium and uranium.

The "real waste" radioactive sludge and the granular activated carbon (commercial brand identification name "C-200 GAC) used in these tests were obtained, respectively, from the bottom of the tank $50 \mathrm{H}$ at the Savannah River Site and Duratec International. The iron oxide (hematite) was a Fisher Scientific company commercial product. The anhydrous sodium orthophosphate used in this study was derived from hydrated sodium orthophosphate $\left(\mathrm{Na}_{3} \mathrm{PO}_{4} \cdot 12 \mathrm{H}_{2} \mathrm{O}\right)$ by heating of the hydrated salt in stainless steel beaker to above its boiling point for several hours. The resulting solid was then transferred to an oven and maintained at $120{ }^{\circ} \mathrm{C}$ for an hour before bringing it to room temperature in a desiccator. 
WSRC-MS-2004-00822

The verification tests (absorption and loading capacity tests) with the air-dried tank $50 \mathrm{H}$ sludge were performed by contacting a known amount of the solid sludge with cesium-137 decontaminated waste from the Savannah River Site nuclear waste tank farm system. This decontaminated wasted solution still contained all the other standard radionuclides of interest; plutonium, uranium and neptunium at concentrations shown in Tables 1 and 2. In the absorption tests with the tank $50 \mathrm{H}$ solids material, the weight of the tank solids was maintained constant at $5.012 \pm 0.015$ grams. To obtain samples at three different liquid-to-solid ratios of 3,5 and 10, the volumes of the real waste supernate and the synthetic salt solutions were varied. In the "real waste" solution tests, the 5:1 ratio tests were performed in duplicate for verification of reproducibility. The two types of loading tests involved the use of two classes of material, which are the airdried radioactive sludge from the tank $50 \mathrm{H}$ nuclear waste tank at SRS and known components (granular activated carbon, hematite, new ETF carbon or anhydrous sodium phosphate) of the air-dried radioactive sludge from the tank $50 \mathrm{H}$. The loading tests were performed with 5.6 molar sodium synthetic salt solutions (a typical nuclear waste simulant) containing dissolved quantities of the actinides. The composition of the 5.6 molar sodium salt solution (spiked with near saturation levels of uranium and plutonium) is presented in Table 1. This salt solution is typical of the salt compositions of the supernates in the tank storage facilities at SRS. The uranium, plutonium and neptunium concentrations in the simulant used for these studies were stable after preparation. The target concentrations for these actinides in the simulant were, respectively, 10.0, 0.20 and $0.50 \mathrm{mg} / \mathrm{L}$ with a $10 \%$ margin of error. Single, pre-test analytical results for uranium, 
plutonium and neptunium concentrations in the simulant were $10.7,0.192$ and 0.496 $\mathrm{mg} / \mathrm{L}$, respectively.

In these loading tests each "neat" component or the air-dried tank $50 \mathrm{H}$ solids was mixed with a specific volume of simulant solution at different liquid-to-solid ratios (generally, 14:1, 20:1, 24:1, 30:1, 40:1, 50:1 and 60:1). The tests were performed in 150$\mathrm{mL}$ capped polypropylene bottles. A minimum of seven different liquid-to-solid ratio (volume/weight) samples were prepared with the weight of the neat solid test material maintained constant at 0.5 grams. Agitation of each sorbent and simulant mixture was achieved by placing the capped polypropylene bottles in an orbital shaker (Lab-line model C-760) maintained at 175 revolutions per minute. A twenty-four hour shaking of the mixture in an orbital shaker at room temperature $\left(26 \pm 2{ }^{\circ} \mathrm{C}\right)$ was judged sufficient, based on previous experience (reference 1), for attainment of sorption equilibrium. After 24 hours of shaking, the liquid phase was separated from the solid phase using a 0.45 micron nylon filter. A portion of the liquid fraction was diluted with 5.0 $\mathrm{M}$ nitric acid and analyzed for plutonium, neptunium and uranium by inductively coupled plasma mass spectrometry (ICP-MS). Tests with no added solids or controls (simulant solutions only) were featured in each test set as controls for preparation errors, instrumental biases and unexpected removal mechanisms such as sorption onto polypropylene bottle walls. The controls were also subjected to the same separation and acid dilution techniques described above. Apart from runs involving sodium phosphate, the sample solutions were not analyzed for uranium since previous tests showed that none of the "neat" materials were found to remove significant amounts of uranium ${ }^{1}$. 
WSRC-MS-2004-00822

\section{RESULTS AND DISCUSSION}

Figures 1 and 2 show, respectively, overlay plots for the 24 hour-elapsed time actinide concentration changes as a function of the liquid-to-solid ratios for the tests with cesium-137 decontaminated real waste and the synthetic salt solutions in contact with airdried tank $50 \mathrm{H}$ solid (absorption tests). In both overlay plots, as the liquid-to-solid ratios decrease (increase in air-dried tank $50 \mathrm{H}$ solid fraction) the amount of plutonium and neptunium precipitated or lost from the liquid phase increased. This behavior is consistent with a typical sorption suggesting that plutonium and neptunium are sorbing onto one or more of the components in the air-dried tank $50 \mathrm{H}$ solid. There is no measurable loss of uranium at all ratios with changes in liquid-to-solid ratio. Therefore, one concludes that there exist some components of the air-dried tank $50 \mathrm{H}$ solid material which have significant affinity for both plutonium and neptunium but not for uranium.

\section{A. Loading of Plutonium and Neptunium onto Air-dried Tank 50H Solid}

The results for the loading curve generated as a result of contacting the synthetic salt solution spiked with plutonium, uranium and neptunium with the air-dried tank $50 \mathrm{H}$ solid (real waste sludge bottom) are shown in Figures 3 and 4, respectively. Each plot shows on the y-axis microgram quantities of the selected actinide per gram of solid sorbent while the $\mathrm{x}$-axis shows the final actinide concentration in the liquid phase (in this case the nuclear waste supernate). The extrapolated maximum loading capacities for these two actinides in the synthetic salt solution are $2.01 \mathrm{ug} \mathrm{Pu} / \mathrm{gram}$ of air-dried tank $50 \mathrm{H}$ solid ( $\mathrm{y}=-0.3335 \mathrm{x}^{2}+65.497 \mathrm{x}-1205.9$ for figure 3$)$ and $4.48 \mathrm{ug} \mathrm{Np} / \mathrm{gram}$ of air-dried $\operatorname{tank} 50 H$ solid $\left(y=-0.0257 x^{2}+21.68 x+128.29\right.$ for figure 4$)$. 
WSRC-MS-2004-00822

\section{B. Pu, Np and U Loading onto Activated carbon, Hematite and $\mathrm{Na}^{+}$phosphate}

Loading curves for plutonium, neptunium and uranium were calculated for various "neat" component sorbents using results from equilibrium tests over a range of simulant-to-solid ratios. From previous studies none of the other sorbents, with the exception of sodium phosphate, had shown any measurable uranium uptake, the only uranium loading test performed was with sodium phosphate.

The concentration of each actinide on the solid phase was calculated from the difference between the initial and final solution concentration. The solids were not analyzed. Figures 5-8 show plutonium-239 and neptunium-237 loading curves, respectively, on granular activated carbon and hematite after 24 hours contact with the simulant solution at room temperature. Figures 9 and 10 show, respectively, the loading curves for $\mathrm{Np}$ and $\mathrm{U}$ on sodium phosphate after 24 hours of contact with the simulated salt solution bearing these actinides.

Some of the loading curves presented in the graphs, for example Figure 8 insert A for loading of neptunium onto hematite, do not have sufficient data points to clearly characterize the maximum loading area of the curve, which is the plateau region of the Langmuir isotherm. The sorption equilibrium for these actinides under these conditions may not have been attained after 24 hours of contacting them with the sorbents. To estimate what the maximum actinide loading values are at the plateau region of the curves a second degree polynomial fitting was used for all the loading data. The use of a second degree polynomial fitting function for the loading curve data applies only up to the inflection point of the curve and not beyond that point and only if that point falls 
WSRC-MS-2004-00822

within the data set. As a caution, these equations may not be used to extrapolate to values outside the data set.

Thus, a second degree polynomial regression of the data, Figures 3 through 10 provides the following equations for estimating maximum loading of plutonium-239, neptunium-237, and uranium (sodium phosphate only) on these sorbents:

\section{Plutonium-239}

$\mathrm{y}=-9 \mathrm{E}-05 \mathrm{x}^{2}+0.037 \mathrm{x}-0.134$ for GAC------------------Figure 5

$y=-4 E-03 x^{2}+0.0959 x$ for hematite ------------------Figure 7

\section{Neptunium-237}

$\mathrm{y}=-5 \mathrm{E}-05 \mathrm{x}^{2}+0.04 \mathrm{x}+0.163$ for $\mathrm{GAC}$------------------Figure 6

$\mathrm{y}=-3 \mathrm{E}-05 \mathrm{x}^{2}+0.039 \mathrm{x}-0.303$ for hematite -------------Figure 8

$y=-38.42 x^{2}+32.55 x-0.130$ for sodium phosphate ----Figure 9

\section{Uranium}

$\mathrm{y}=-4.183 \mathrm{x}^{2}+55.584 \mathrm{x}$ for sodium phosphate---------------Figure 10 ,

where $\mathrm{y}$ is loading capacity in units of $\mu \mathrm{g}$ actinide per gram of "neat" sorbent material and $\mathrm{x}$ is the final actinide concentration in $\mu \mathrm{g} / \mathrm{L}$. By equating the first derivatives of each loading capacity equation above to zero and solving for $\mathrm{x}$ values, the maximum loading capacities (y-values) for plutonium and neptunium were determined from the absorption data.

Table 3 shows a summary of loading data for plutonium, neptunium and uranium on, respectively, Tank $50 \mathrm{H}$ solids, "neat" granular activated carbon, "neat" hematite and sodium phosphate. Based on these loading curve data, "neat" hematite and "neat" granular activated carbon show the highest affinity for both plutonium and neptunium. 
Loading on hematite were, respectively, $5.5 \pm 0.38 \mu \mathrm{g}$ Pu per gram hematite and a $>10$ $\mu \mathrm{g}$ Np per gram hematite. While, loading on granular activated carbon were, respectively, $7.9 \pm 0.52 \mu \mathrm{g}$ Np per gram of granular activated carbon and $3.4 \pm 0.22 \mu \mathrm{g}$ Pu per gram granular activated carbon. Sodium phosphate (used here as a reference sorbent for uranium) as expected exhibited a very high affinity for uranium. Its affinity for neptunium was comparable to that of the granular activated carbon, although it showed no measurable affinity for plutonium. Both uranium and neptunium were readily absorbed or precipitated in the presence of anhydrous sodium phosphate. The loading capacity values on anhydrous sodium phosphate were, respectively, $184.6 \pm 18.5 \mu \mathrm{g} \mathrm{U}$ per gram of anhydrous sodium phosphate and $6.8 \pm 0.6 \mu \mathrm{g}$ Np per gram of anhydrous sodium phosphate.

The affinity of these sorbents for actinides in a non caustic or neutral environment is well documented ${ }^{3,4,5}$. In this study it has been shown that the precipitation of these nuclear materials from solution in the presence of these sorbents is possible. Loading capacity information provides a basis for estimating the maximum volume of nuclear waste supernates that can be transferred in and out of nuclear waste storage tanks before accumulating sufficient quantities of plutonium to pose a nuclear criticality safety concern. Conversely, the information could be used to determine how much of nuclear waste storage tank solids could be left behind and not present a safety concern due to the accumulation of fissionable materials like plutonium and neptunium.

\section{B. CONCLUSIONS}

Based on a caustic synthetic salt solution simulant bearing plutonium, uranium and neptunium and "real" nuclear waste supernate solution, the loading capacities of 
these actinides onto iron oxide (hematite), activated carbon and anhydrous sodium phosphate have been determined. The loading capacities for plutonium onto granular activated carbon and iron oxide (hematite) in a caustic synthetic salt solution were, respectively, $3.40 .22 \pm$ and $5.5 \pm 0.38 \mu \mathrm{g}$ per gram of sorbent. The loading capacity for plutonium onto a typical nuclear waste storage tank sludge solids was $2.01 \mu \mathrm{g}$ per gram of sludge solids.

The loading capacities for neptunium onto granular activated carbon and iron oxide (hematite) in a caustic synthetic salt solution were, respectively, $7.9 \pm 0.52$ and $>10$ $\mu \mathrm{g}$ per gram of sorbent. The loading capacity for neptunium onto a typical nuclear waste storage tank dehydrated sludge solids was $4.48 \mu \mathrm{g}$ per gram of sludge solids. A typical nuclear waste storage tank solid material did not show any significant affinity for uranium. Sodium phosphate showed significant affinity for both neptunium and uranium, with loading capacities of 6.8 and $184.6 \pm 18.5 \mu \mathrm{g}$ per gram of sorbent, respectively.

Based on these batch experiments the following conclusions are made:

- The removal of plutonium and neptunium from the synthetic salt solution by nuclear waste storage tank solids may be due largely to the presence of the granular activated carbon and transition metal oxides.

- Granular activated carbon and iron oxides (hematite) show measurable affinity for both plutonium and neptunium.

- Sodium phosphate (used here as a reference sorbent for uranium), as expected, exhibited high affinity for uranium and neptunium, but failed to show any measurable affinity for plutonium. 


\section{ACKNOWLEDGEMENTS}

The authors thank the Savannah River National Laboratory Analytical Development Section personnel, in particular, W. Boyce, M. Malek, David and Cecilia Diprete and J. Hart for performing actinide, anion, and other metal analyses. We also thank M. S. Blume for assistance in running the experiments. 
WSRC-MS-2004-00822

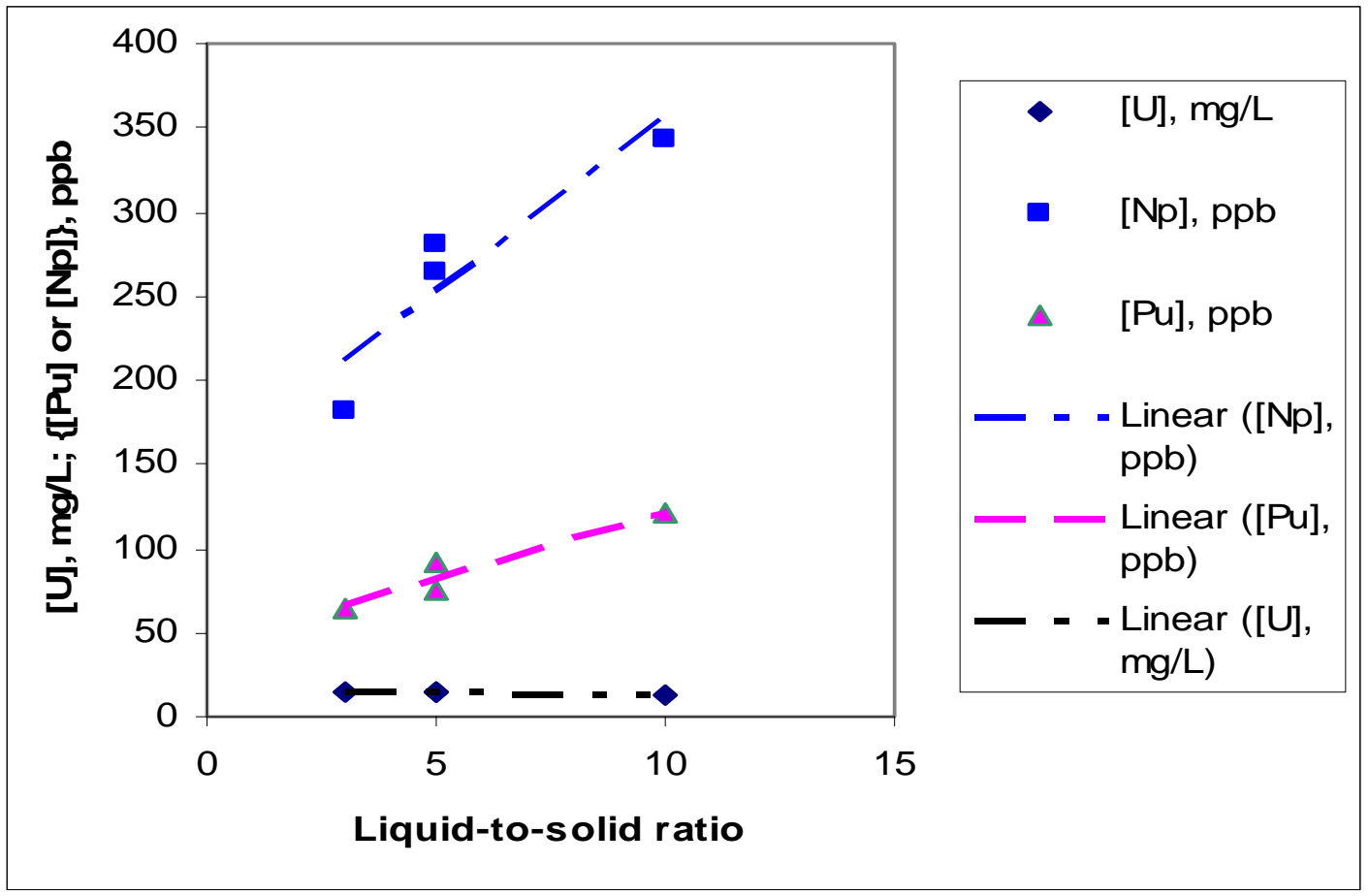

Fig. 1. A typical overlay actinide absorption plot at different liquid-to-solid ratios for nuclear waste sludge solid in a nuclear waste supernate. 
WSRC-MS-2004-00822

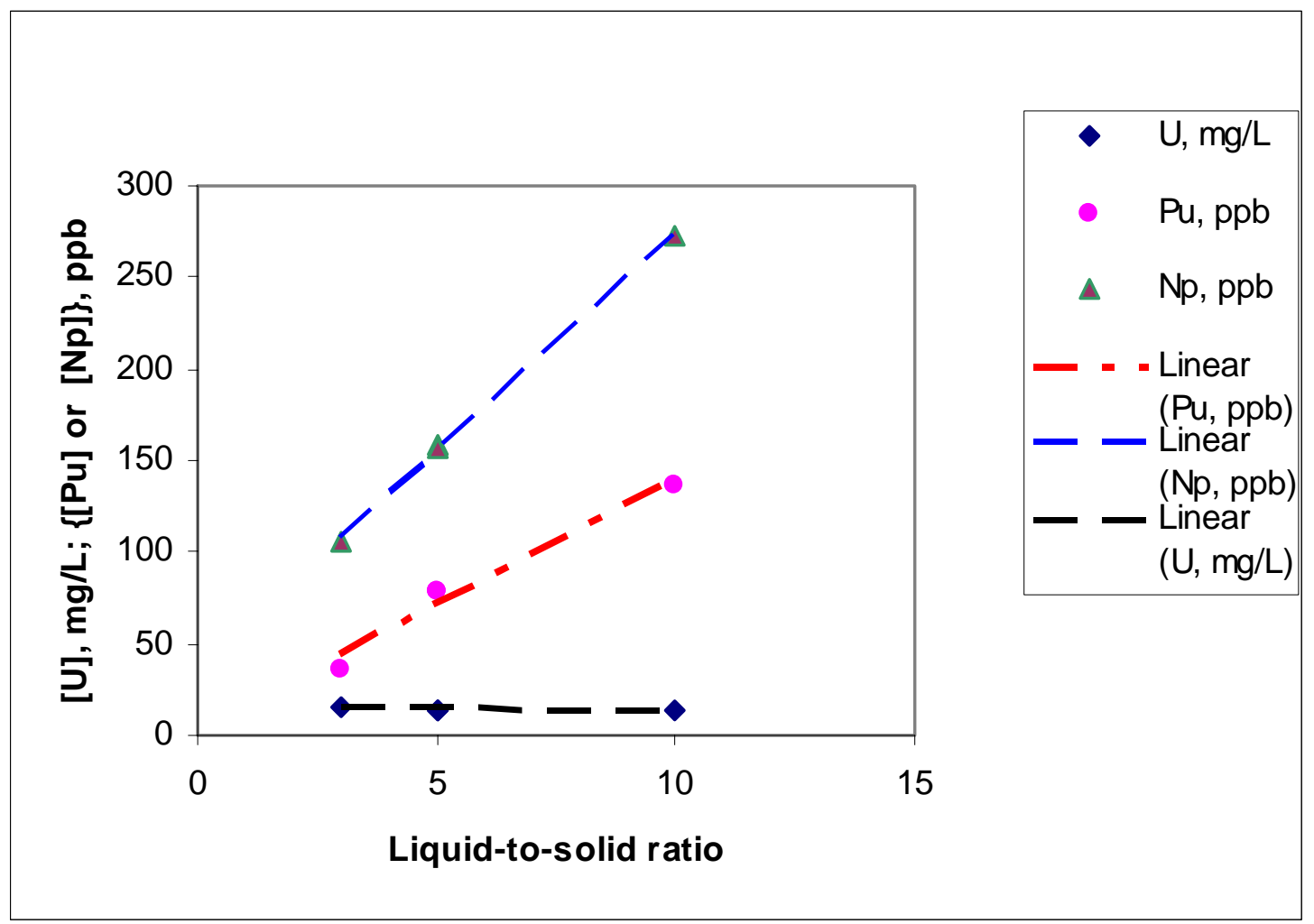

Fig. 2. A typical overlay actinide absorption plot at different liquid-to-solid ratios for nuclear waste sludge solid in a synthetic salt solution. 
WSRC-MS-2004-00822

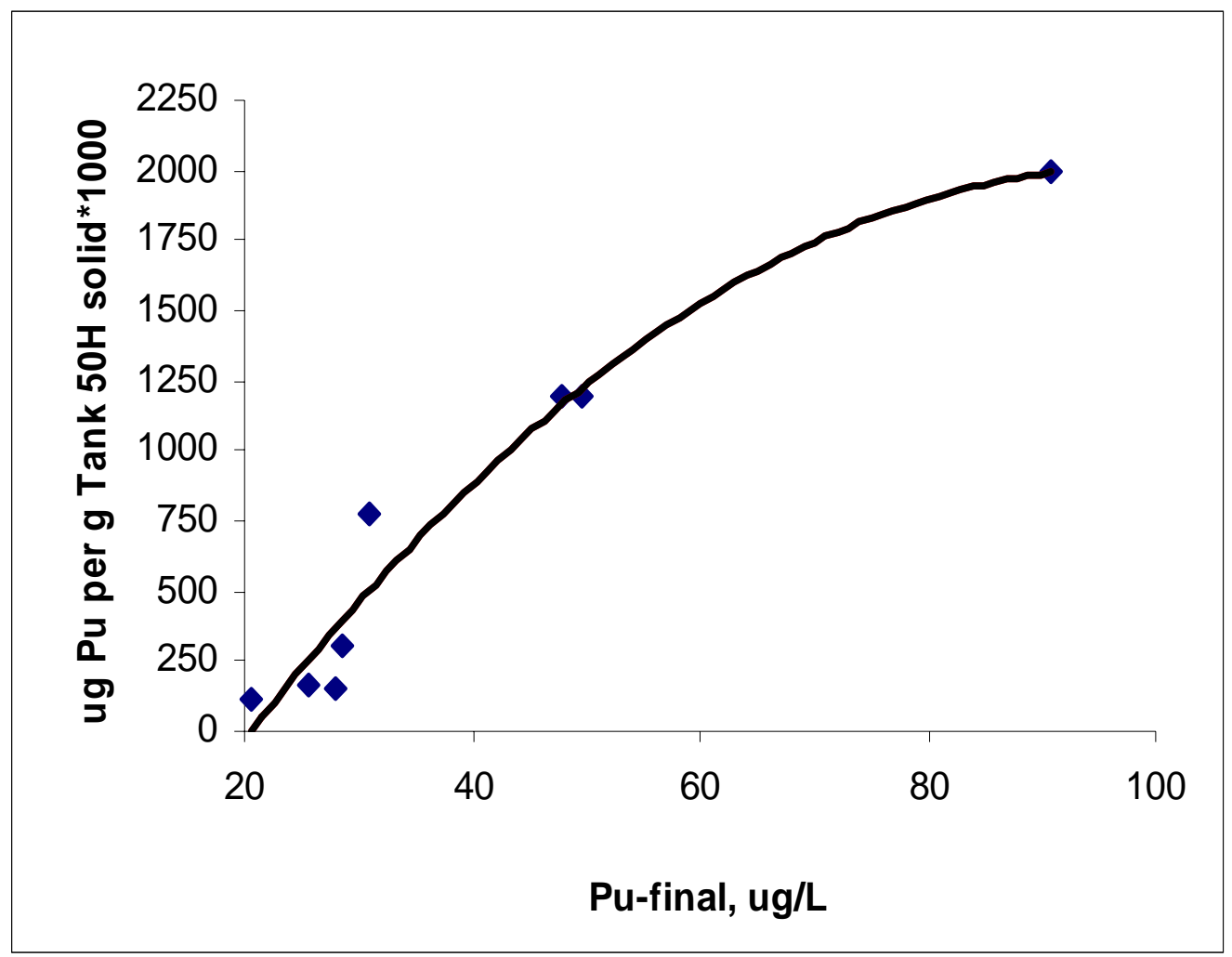

Fig. 3. A typical plutonium loading curve: Nuclear waste storage tank solid material in a nuclear waste supernate. 
WSRC-MS-2004-00822

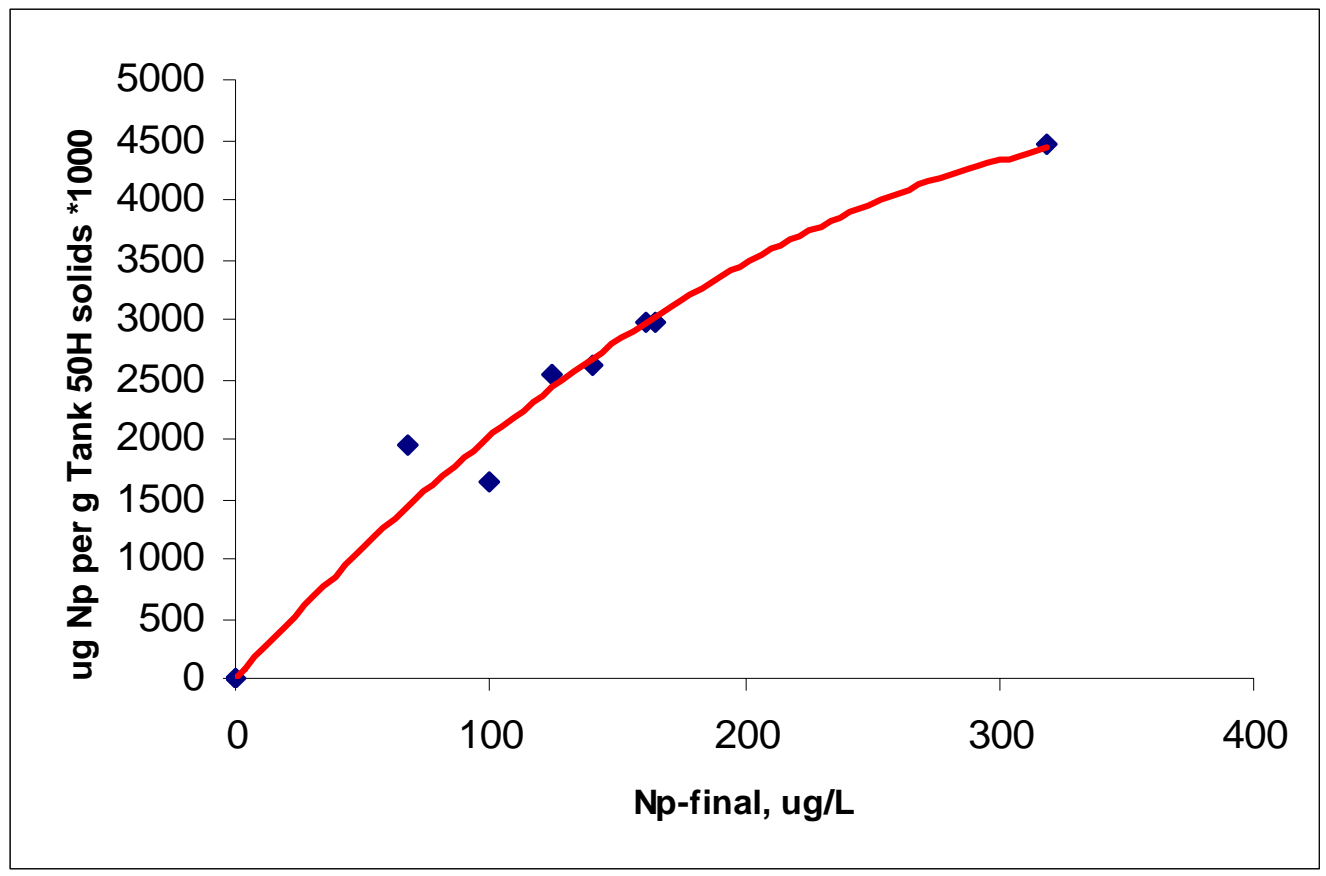

Fig. 4. A typical Neptunium loading curve: Nuclear waste storage tank solid material in a nuclear waste supernate. 
WSRC-MS-2004-00822

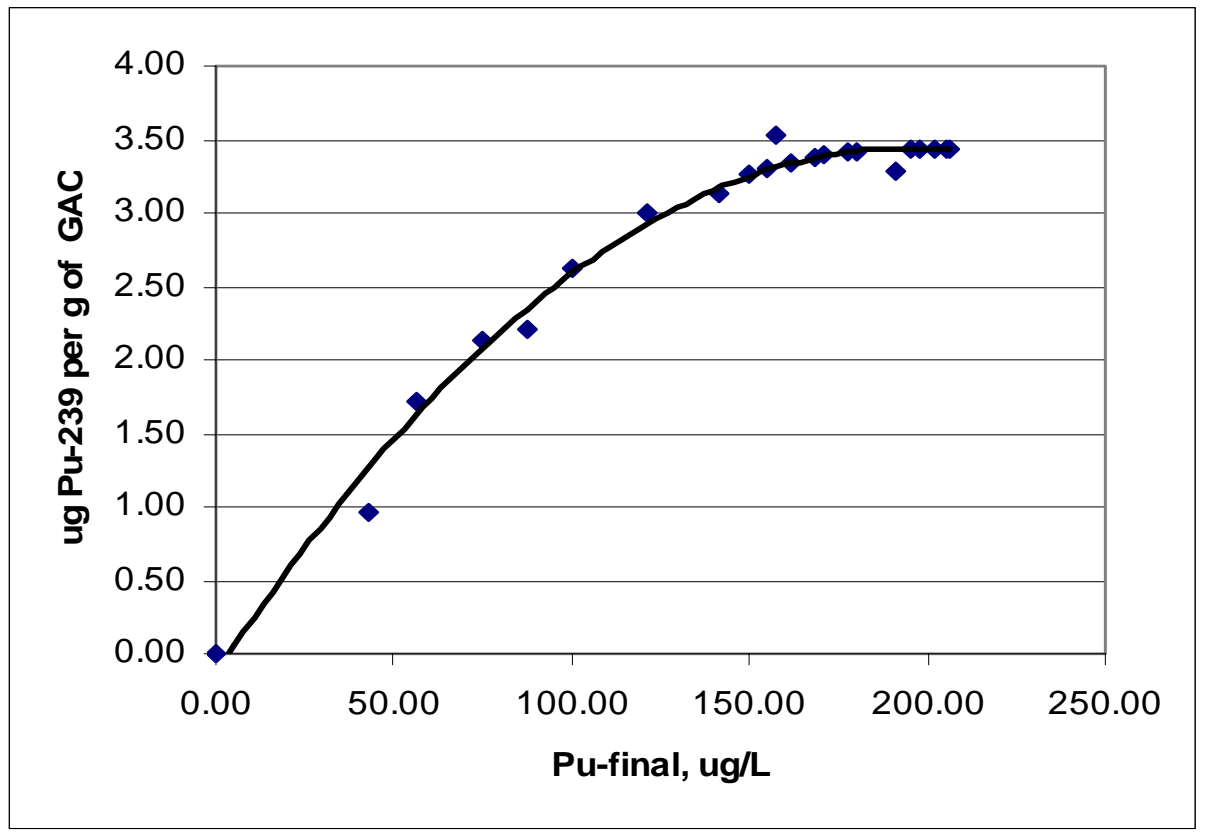

Fig. 5. A typical plutonium loading curve: Granular activated carbon in a synthetic salt solution spiked with actinides. 
WSRC-MS-2004-00822

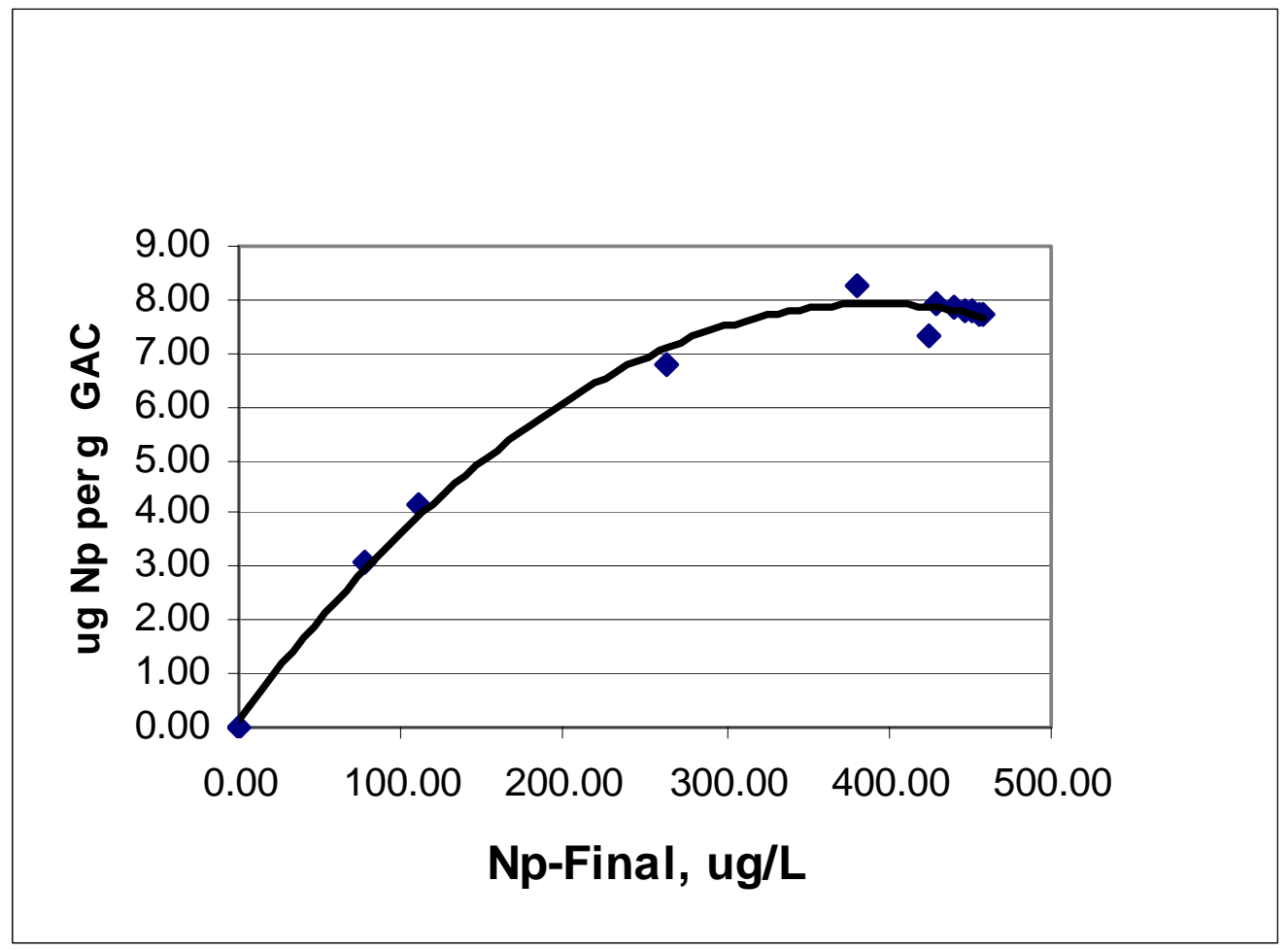

Fig. 6. A typical neptunium loading curve: Granular activated carbon in a synthetic salt solution spiked with actinides. 
WSRC-MS-2004-00822

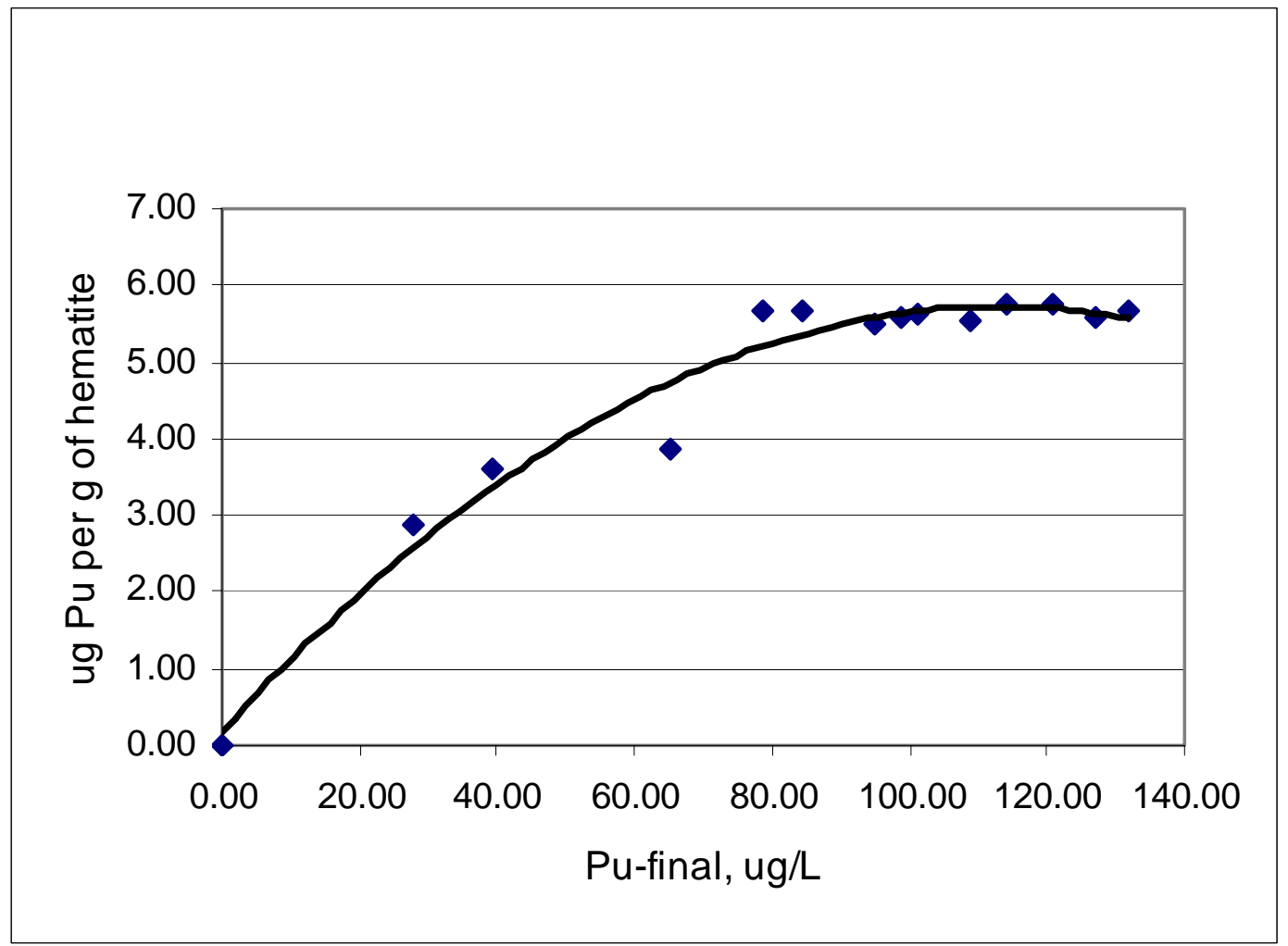

Fig. 7. A typical plutonium loading curve: Hematite in synthetic salt solution spiked with actinides. 


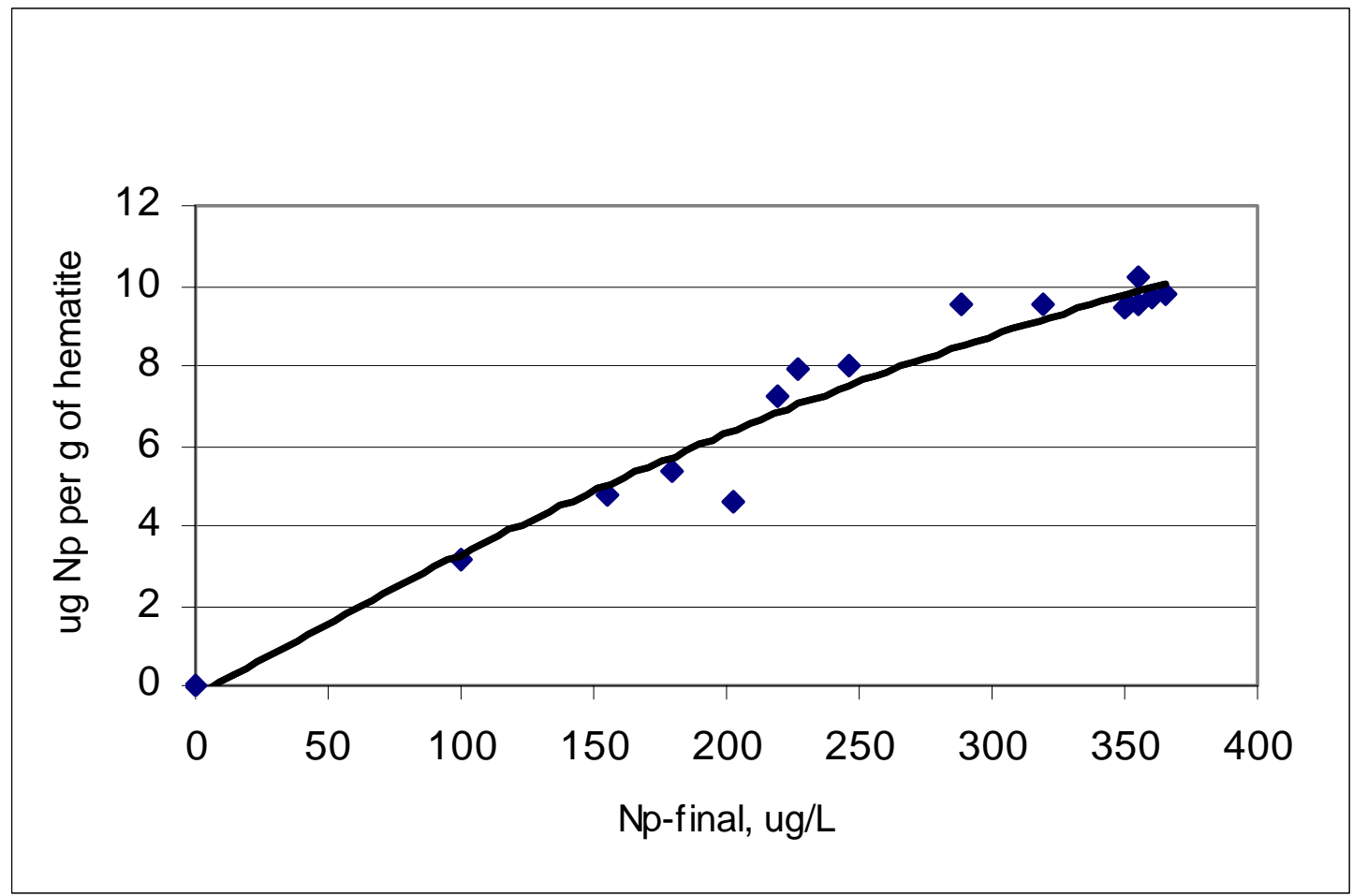

Fig. 8. A typical neptunium loading curve: Hematite in synthetic salt solution spiked with actinides. 


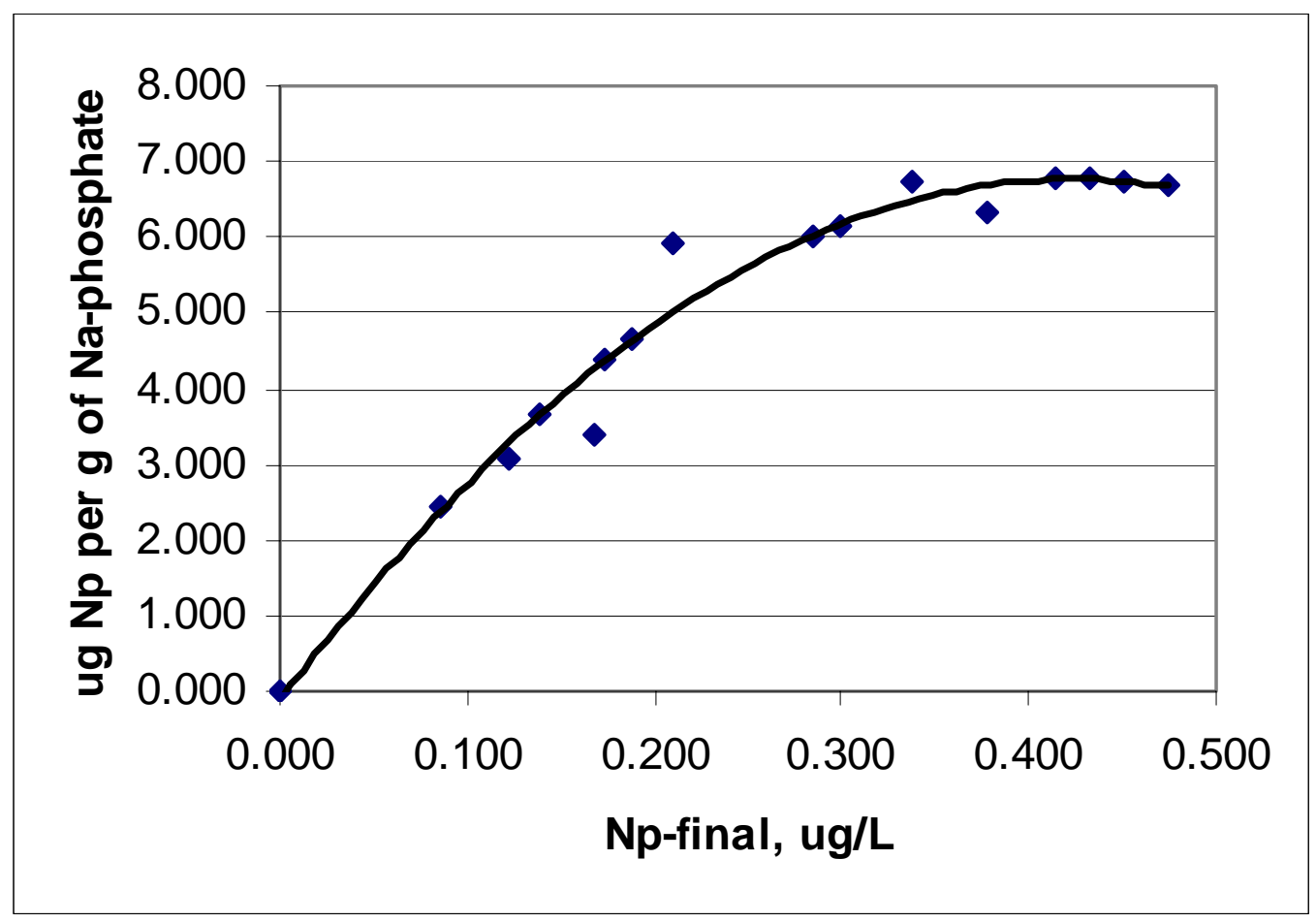

Fig. 9. A typical neptunium loading curve: Sodium phosphate in synthetic salt solution spiked with actinides. 
WSRC-MS-2004-00822

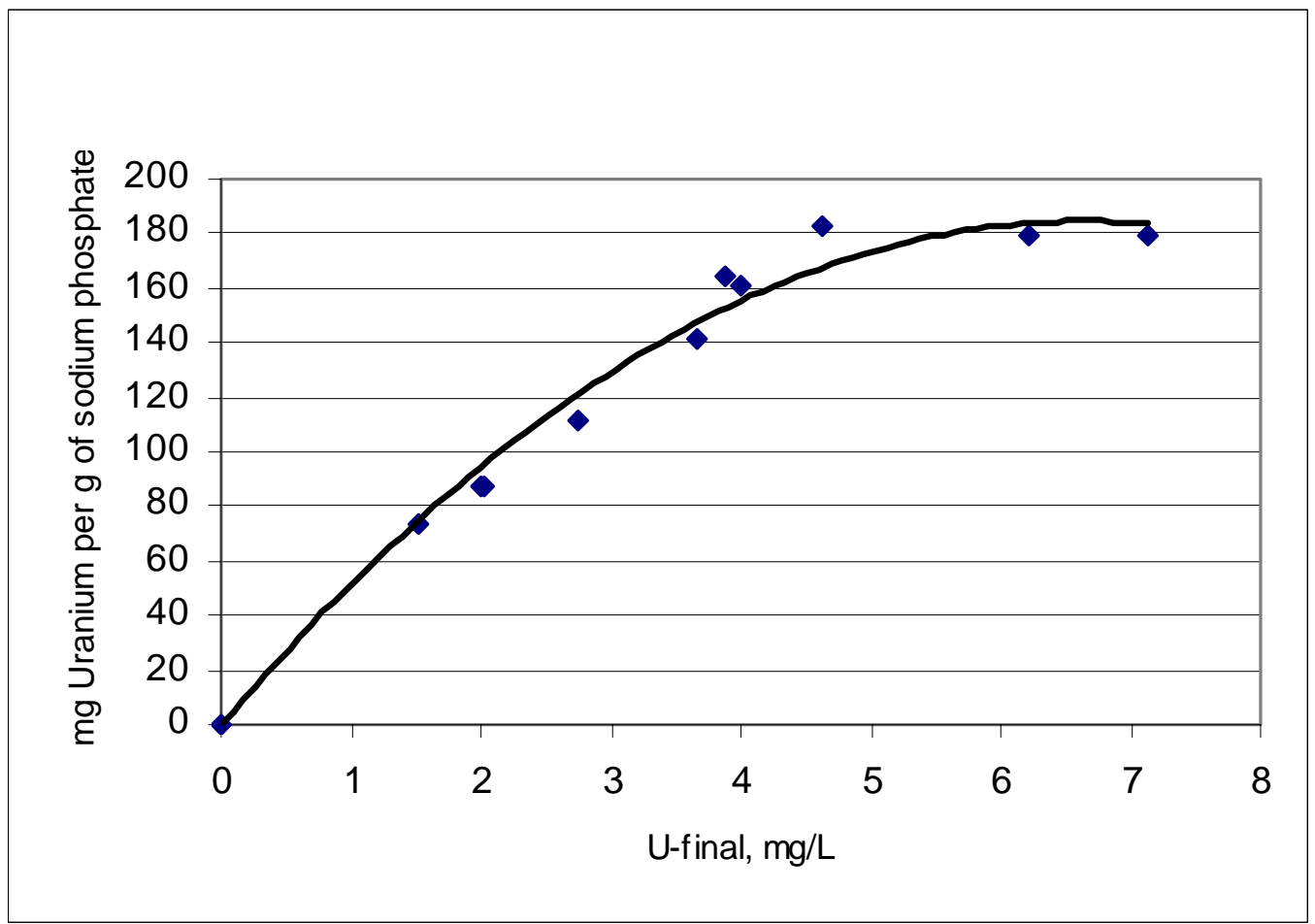

Fig. 10. A typical uranium loading curve: Sodium phosphate in synthetic salt solution spiked with actinides. 
Table 1. Spiked synthetic salt solution composition

\begin{tabular}{|l|c|c|}
\hline Component & Target concentration & Units \\
\hline & & \\
\hline Total $\mathrm{Na}$ & 5.60 & $\mathrm{M}$ \\
\hline Free $\mathrm{NaOH}$ & $1.33 \mathrm{E}+00$ & $\mathrm{M}$ \\
\hline $\mathrm{NaNO}_{3}$ & $2.60 \mathrm{E}+00$ & $\mathrm{M}$ \\
\hline $\mathrm{NaNO}_{2}$ & $1.64 \mathrm{E}-01$ & $\mathrm{M}$ \\
\hline $\mathrm{Na}_{2} \mathrm{SO}_{4}$ & $5.21 \mathrm{E}-01$ & $\mathrm{M}$ \\
\hline $\mathrm{Na}_{2} \mathrm{CO}_{3}$ & $2.60 \mathrm{E}-02$ & $\mathrm{M}$ \\
\hline $\mathrm{NaAl}(\mathrm{OH})_{4}$ & $4.29 \mathrm{E}-01$ & $\mathrm{M}$ \\
\hline & & \\
\hline Total U & $10.0 \pm 1$ & $\mathrm{mg} / \mathrm{L}$ \\
\hline Total $\mathrm{Pu}$ & $0.20 \pm 0.02$ & $\mathrm{mg} / \mathrm{L}$ \\
\hline $\mathrm{Np}-237$ & $0.50 \pm 0.050$ & $\mathrm{mg} / \mathrm{L}$ \\
\hline
\end{tabular}

Table 2. Real waste supernate composition

\begin{tabular}{|l|c|c|}
\hline \multicolumn{1}{|c|}{ Component } & Concentration & Units \\
\hline $\mathrm{Na}$ & 9.16 & $\mathrm{M}$ \\
\hline $\mathrm{K}$ & 0.06 & $\mathrm{M}$ \\
\hline $\mathrm{Ag}$ & 9.46 & $\mathrm{mg} / \mathrm{L}$ \\
\hline $\mathrm{Ba}$ & 2.82 & $\mathrm{mg} / \mathrm{L}$ \\
\hline $\mathrm{Ca}$ & 19.92 & $\mathrm{mg} / \mathrm{L}$ \\
\hline $\mathrm{Cd}$ & 2.16 & $\mathrm{mg} / \mathrm{L}$ \\
\hline $\mathrm{Cr}$ & 64 & $\mathrm{mg} / \mathrm{L}$ \\
\hline $\mathrm{Mo}$ & 78 & $\mathrm{mg} / \mathrm{L}$ \\
\hline $\mathrm{Free} \mathrm{OH}^{-}$ & 6.81 & $\mathrm{M}$ \\
\hline $\mathrm{NO}_{3-}{ }^{-}$ & 0.95 & $\mathrm{M}$ \\
\hline $\mathrm{NO}_{2}{ }^{-}$ & 0.68 & $\mathrm{M}$ \\
\hline $\mathrm{AlO}_{2}{ }^{-}$ & 0.30 & $\mathrm{M}$ \\
\hline $\mathrm{SO}_{4}{ }^{2-}$ & 0.07 & $\mathrm{M}$ \\
\hline $\mathrm{CO}_{3}{ }^{2-}$ & 0.11 & $\mathrm{M}$ \\
\hline $\mathrm{PO}_{4}{ }^{3-}$ & 0.01 & $\mathrm{M}$ \\
\hline & & \\
\hline $\mathrm{Total}_{\text {Tranium }}$ & $19 \pm 1$ & $\mathrm{mg} / \mathrm{L}$ \\
\hline $\mathrm{Total}^{-}$Plutonium & $150 \pm 5$ & $\mu \mathrm{g} / \mathrm{L}$ \\
\hline Total Neptunium-237 & 650 & $\mu \mathrm{g} / \mathrm{L}$ \\
\hline
\end{tabular}


Table 3. Loading capacity summary for the actinides

\begin{tabular}{|l|c|c|c|}
\hline Sorbents & $\begin{array}{l}\text { Maximum loading } \\
\mu \mathrm{g} / \mathrm{g} \text { solid }\end{array}$ & $\begin{array}{l}\text { Maximum loading } \\
\mu \mathrm{g} / \mathrm{g} \text { solid }\end{array}$ & $\begin{array}{l}\text { Maximum loading } \\
\mu \mathrm{g} / \mathrm{g} \text { solid }\end{array}$ \\
\hline & & $\mathrm{Np}$ & $\mathrm{U}$ \\
\hline Actinide & $\mathrm{Pu}$ & $\mathbf{4 . 4 8}$ & $\mathbf{N A}$ \\
\hline Tank 50H solids & $\mathbf{2 . 0 1}$ & $\mathbf{7 . 9} \pm \mathbf{0 . 5 2}$ & $\mathbf{N A}$ \\
\hline & & & $\mathbf{N A}$ \\
\hline Granular activated carbon & $\mathbf{3 . 4} \pm \mathbf{0 . 2 2}$ & $\mathbf{1 0 . 0}$ & \\
\hline & & & $\mathbf{1 8 4 . 6} \pm \mathbf{1 8 . 5}$ \\
\hline Iron oxide (hematite) & $\mathbf{5 . 5} \pm \mathbf{0 . 3 8}$ & $\mathbf{6 . 8}$ & \\
\hline & & &
\end{tabular}

$\mathrm{NA}=$ No measurable absorption of uranium. 
WSRC-MS-2004-00822

\section{Keywords:}

Activated Carbon, Iron Oxide (hematite) and Sodium Phosphate

\section{REFERENCES}

${ }^{1}$ Oji 1. N. and Hobbs D. T., "Evaluation of the Effects of Tank 50H Solids on Dissolved Uranium, Plutonium and Neptunium”, WSRC-RP-2003-00224, Rev. 0, April 17, 2003.

${ }^{2}$ Wilmarth, W.R., "Results of Sample Analysis from Solids Removed from Tank 50H", WSRC-TR-2002-00506, November 1, 2002.

${ }^{3}$ S. Nagasaki, S. Tanaka and A. Suzuki, "Influence of Fe (III) colloids on Np (V) migration through quartz-packed columns," Journal of Nuclear Science Technology, 31(2), pp 143-150 (Feb. 1994).

4 M. Kohler, B. D. Honeyman and J. O. Leckie “ Neptunium (V) sorption on hematite $\left(\alpha-\mathrm{Fe}_{2} \mathrm{O}_{3}\right)$ in aqueous suspension: the effect of $\mathrm{CO}_{2}$," Radiochim. Acta 85, 33-48 (1999).

5 J. L. Means, D. A. Crerar, M. P. Borscsik and J. O. Duguid, “Adsorption of Co and selected actinides by Mn and Fe oxides in soils and sediments," Geochim. Cosmochim. Acta, 42, 1763-1773 (1978). 